\title{
A Proinflammatory Function of Toll-Like Receptor 2 in the Retinal Pigment Epithelium as a Novel Target for Reducing Choroidal Neovascularization in Age-Related Macular Degeneration
}

Lili Feng, ${ }^{*}$ Meihua Ju, ${ }^{\dagger \ddagger}$ Kei Ying V. Lee, ${ }^{\dagger \ddagger}$ Ashley Mackey, ${ }^{*}$ Mariasilvia Evangelista, ${ }^{*}$ Daiju Iwata, ${ }^{\dagger \dagger}$ Peter Adamson, Kameran Lashkari, ${ }^{*}$ Richard Foxton, ${ }^{\dagger \ddagger}$ David Shima, ${ }^{\dagger \ddagger}$ and Yin Shan $\mathrm{Ng}^{*}$

From the Department of Ophthalmology, * Schepens Eye Research Institute of Massachusetts Eye and Ear, Harvard Medical School, Boston, Massachusetts; and the Department of Ocular Biology and Therapeutics, ${ }^{\ddagger}$ University College of London Institute of Ophthalmology, ${ }^{\dagger}$ London, United Kingdom

\author{
Accepted for publication \\ June 8, 2017. \\ Address correspondence to \\ Yin Shan Ng, Ph.D., Schepens \\ Eye Research Institute of \\ Massachusetts Eye and Ear, \\ Department of Ophthalmology, \\ Harvard Medical School, 20 \\ Staniford St., Boston, MA \\ 02114. E-mail: eric_ng@meei. \\ harvard.edu.
}

\begin{abstract}
Current treatments for choroidal neovascularization, a major cause of blindness for patients with agerelated macular degeneration, treat symptoms but not the underlying causes of the disease. Inflammation has been strongly implicated in the pathogenesis of choroidal neovascularization. We examined the inflammatory role of Toll-like receptor 2 (TLR2) in age-related macular degeneration. TLR2 was robustly expressed by the retinal pigment epithelium in mouse and human eyes, both normal and with macular degeneration/choroidal neovascularization. Nuclear localization of $\mathrm{NF}-\kappa \mathrm{B}$, a major downstream target of TLR2 signaling, was detected in the retinal pigment epithelium of human eyes, particularly in eyes with advanced stages of age-related macular degeneration. TLR2 antagonism effectively suppressed initiation and growth of spontaneous choroidal neovascularization in a mouse model, and the combination of anti-TLR2 and antivascular endothelial growth factor receptor 2 yielded an additive therapeutic effect on both area and number of spontaneous choroidal neovascularization lesions. Finally, in primary human fetal retinal pigment epithelium cells, ligand binding to TLR2 induced robust expression of proinflammatory cytokines, and end products of lipid oxidation had a synergistic effect on TLR2 activation. Our data illustrate a functional role for TLR2 in the pathogenesis of choroidal neovascularization, likely by promoting inflammation of the retinal pigment epithelium, and validate TLR2 as a novel therapeutic target for reducing choroidal neovascularization. (Am J Pathol 2017, 187: 2208-2221; http://dx.doi.org/10.1016/j.ajpath.2017.06.015)
\end{abstract}

Investigations into the pathophysiology of age-related macular degeneration (AMD) have yielded valuable molecular targets for the treatment of choroidal neovascularization (CNV), including vascular endothelial growth factor $\mathrm{A}$ (VEGF). ${ }^{1,2}$ Although anti-VEGF treatment effectively suppresses the vascular hyperpermeability associated with $\mathrm{CNV}$, this treatment mainly addresses a disease end point rather than the molecular mechanism of CNV development. ${ }^{3}$ Experimental overexpression of VEGF by either the retina or the retinal pigment epithelium (RPE) in different mouse models did not result in the development of $\mathrm{CNV},{ }^{4-7}$ suggesting that
Supported by the BrightFocus Foundation Macular Degeneration Research (MDR) grant M2015214 (Y.S.N.), a grant from the GrimshawGudewicz Charitable Foundation (Y.S.N.), and the NIH National Eye Institute Core grant P30EY003790 for Schepens Eye Research Institute. UCL Institute of Ophthalmology is supported by the NIHR Biomedical Research Centre for Ophthalmology (UK).

Disclosures: None declared.

Current address of L.F., Department of Ophthalmology, EYE and ENT Hospital of Fudan University, Shanghai, China; of M.J., Toxikon Corporation, Bedford, MA; of R.F., Roche Pharma Research and Early Development, Ophthalmology Discovery and Biomarkers, Roche Innovation Center Basel, F Hoffmann-La Roche Ltd, Basel, Switzerland. 
pathologic stimuli in addition to elevated VEGF are required for CNV pathogenesis and that anti-VEGF therapy has critical limitations. Patients receiving anti-VEGF therapies require intraocular injections every 4 to 8 weeks, potentially lifelong, to maintain their vision. ${ }^{8}$ The beneficial effects of anti-VEGF therapy appear to diminish after the third or fourth year of treatment, ${ }^{9-11}$ and a significant proportion of patients with CNV do not respond to anti-VEGF therapy. ${ }^{12}$ Finally, there is emerging evidence that chronic VEGF neutralization may lead to ocular side effects. ${ }^{13-15}$ Thus, there is a clear imperative for an alternative therapy that will intervene earlier in the disease process and provide a means for more-effective, long-term management of AMD.

Dysregulated inflammation may play a critical role in the development of $\mathrm{AMD},{ }^{16}$ and some observations suggest autoimmune contributions. ${ }^{17}$ Numerous studies point to involvement of the innate immune system, including interactions among the complement system, ${ }^{18-21}$ leukocytes, ${ }^{22-25}$ and pattern recognition receptors, such as the Toll-like receptors (TLRs), ${ }^{26,27}$ in AMD and CNV. ${ }^{28}$ The TLRs are pattern recognition receptors that can bind to and sense both pathogen-associated molecular patterns (PAMPs) and self-derived danger-associated molecular patterns (DAMPs), then mediate appropriate inflammatory and repair responses. ${ }^{26,29}$ TLR2 is expressed primarily on plasma membranes and is essential for the recognition of microbial lipopeptides (PAMPs) and end products of lipid oxidation (DAMPs). ${ }^{30,31}$ The $\omega$-(2-carboxy-ethyl) pyrrole (CEP) adducts, end products of lipid oxidation, are reportedly endogenous ligands for TLR 2 and have been shown to promote angiogenesis in a wound healing model by directly activating TLR2 on endothelial cells. ${ }^{31,32}$

Microenvironments with high oxidative stress, including the highly metabolically active neural retina, ${ }^{33}$ promote lipid oxidation and formation of CEP adducts. This could result in chronic TLR2 activation, inflammation, and, eventually, angiogenesis. Interestingly, there is evidence that CEP adducts and DAMPs in general do not directly activate TLR2, but instead they potentiate the activation of TLR2 by PAMPs. ${ }^{34,35}$ This suggests that direct TLR2 activation by pathogens, coupling with potentiation or priming of the TLR2 activity by DAMPs, could be important in the pathogenesis of CNV. Indeed, TLR2 activation by Chlamydia pneumoniae has been shown to enhance the expansion of laser-induced CNV. ${ }^{36}$ Increased TLR2 expression and reactivity in peripheral blood mononuclear cells from patients with AMD support the concept that TLR2 may be involved in disease pathogenesis, ${ }^{37}$ and, intriguingly, C. pneumoniae was detected in human CNV samples but not in control eyes without AMD, ${ }^{38}$ highlighting a potential role for pathogenmediated TLR2 activation in the pathologic process.

In this study, we investigated the expression of TLR2 in human AMD at different stages, including CNV, and in agematched controls without disease to assess potential involvement of TLR2 in AMD pathogenesis. To examine the functional role of this receptor in the initiation and growth of pathologic choroidal vessels, neutralizing antibodies against TLR2 were used in a mouse model of spontaneous CNV. Mechanisms for TLR2 activation were examined by treating human primary RPE cells with a combination of different synthetic and natural bacterial ligands and CEP adducts. Results of these studies suggest that dysregulated TLR2 activation in the RPE may play an important role in the pathogenesis of CNV by modulating the inflammatory response of the RPE. These studies point to the TLR2 pathway as a potential therapeutic target to prevent blindness in patients with AMD.

\section{Materials and Methods}

\section{Immunohistochemistry of Human Tissues}

Formalin-fixed and paraffin-embedded sections from deidentified human donor eyes, with (77 to 90 years old) and without (77 years old) AMD, were deparaffinized in $100 \%$ xylene, rehydrated in a series of ethanol, and washed in phosphate-buffered saline (PBS). Sections were processed for immunohistochemistry using the following antibodies: anti-TLR2 (dilution 1:500; Abcam, Cambridge, MA), NFкB p65 (dilution 1:300; Cell Signaling, Danvers, MA), and control IgGs (goat $\operatorname{IgG}$ at dilution 1:500 or rabbit $\operatorname{IgG}$ at dilution 1:300; Sigma-Aldrich, St. Louis, MO). Epitope retrieval was accomplished in boiling citrate buffer ( $\mathrm{pH} 6)$. Sections were incubated in $3 \% \mathrm{H}_{2} \mathrm{O}_{2}$ in methanol to inhibit endogenous peroxidases, then blocked in protein blocking solution, and incubated in primary antibody overnight at $4^{\circ} \mathrm{C}$. The next day, sections for TLR2 staining were incubated in a goat probe for 15 minutes, followed by alkaline phosphatase-polymer that conjugates to the probe (Goat-onRodent AP-polymer kit; Biocare Medical, Concord, CA) for 30 minutes and then visualized with the Vulcan Fast Red chromogenic substrate kit (FR805; Biocare Medical). For $\mathrm{NF}-\kappa \mathrm{B}$ p65 staining, sections were incubated in MACH2 Rabbit horseradish peroxidase-polymer (Biocare Medical) for 30 minutes and then visualized with the Deep Space Black Chromogenic substrate kit (BRI4015; Biocare Medical). Finally, the slides with (for TLR2) and without (for NF- $\kappa \mathrm{B}$ p65) hematoxylin counterstaining (Gill no. 3 hematoxylin; Sigma-Aldrich) were mounted with Permount medium (Thermo Fisher Scientific, Waltham, MA) before imaging using an Axioskop 2 MOT Plus microscope (Carl Zeiss Inc., Thornwood, NY) equipped with an Axiocam MRc color camera (Carl Zeiss Inc.). Axiovision version 4.9.1 (Carl Zeiss Inc.) was used for image acquisition.

\section{Animals}

Six-week-old male wild-type C57BL/6J mice were obtained from Harlan UK Ltd., (Blackthorn, UK) or The Jackson Laboratory (Bar Harbor, ME), and the JR5558 mice displaying spontaneous $\mathrm{CNV}^{39,40}$ were produced from an in-house colony. The animals were fed standard laboratory 
chow, received water ad libitum, and were housed in a temperature-controlled environment with a 12-hour daynight cycle. For in vivo procedures, mice were anesthetized with a single i.p. injection of a mixture of medetomidine hydrochloride ( $1 \mathrm{mg} / \mathrm{kg}$ body weight; Domitor; Pfizer Animal Health, New York, NY) and ketamine $(60 \mathrm{mg} / \mathrm{kg}$ body weight; Fort Dodge Animal Health Ltd., Southampton, UK) in sterile water. Before procedures involving fluorescein imaging, pupils were dilated with one drop each of $2.5 \%$ phenylephrine hydrochloride (Chauvin Pharmaceuticals Ltd., Kingston-Upon-Thames, UK) and 1\% tropicamide (Bausch and Lomb, Surrey, UK). After the procedures, an i.p. injection of Antisedan (20\%; Orion Pharma, Espoo, Finland) at $0.01 \mathrm{~mL} / 150 \mathrm{~g}$ was used to reverse the effects of the anesthesia. All animal procedures were reviewed and approved according to the British Home Office Animals Scientific Procedures Act 1986 and were performed in accordance with European Directive 86/609/EEC (Environment, European Commission) and the Association for Research in Vision and Ophthalmology Statement for the Use of Animals in Ophthalmic and Vision Research.

\section{Treatment of Spontaneous CNV in JR5558 Mice}

JR5558 mice, ${ }^{39-41}$ which spontaneously generate CNV lesions, were treated with a single intravitreal injection (in $0.8 \mu \mathrm{L}$ ) of rat anti-mouse VEGF receptor-2 (VEGFR2) blocking antibody ( 0.8 or $4.8 \mu \mathrm{g}$ per injection; MAB4431; R\&D Systems, Minneapolis, MN), purified mouse neutralizing anti-mouse TLR2 antibody $(0.8,1.6$, or $3.2 \mu \mathrm{g}$ per injection; mab-mTLR2; InvivoGen, San Diego, CA), a combination of anti-VEGFR2 and anti-TLR2 antibodies $(0.8+0.8 \mu \mathrm{g}$ or $4.8+3.2 \mu \mathrm{g}$ per injection $)$, a mixture of a rat nonimmune, isotype-matched control IgG2 $\alpha$ antibody (4.8 $\mu \mathrm{g}$ per injection; R\&D Systems), mouse isotype-matched control IgG1 antibody (3.2 $\mu \mathrm{g}$ per injection; InvivoGen), or vehicle control at postnatal day 24. CNV was analyzed by fundus fluorescein angiography (FFA) on postnatal day 31,7 days after injection, and eyes were collected at 24 hours after FFA for immunohistologic analysis. Each litter was divided into at least three different treatment groups, including either a vehicle or control IgG group, to minimize the potential interlitter variation of responses to the different treatments. Mice (postnatal day 24) of both sexes were used for the experiments, and at least eight mice were used per treatment group according to prior pilot experiments using the same models. All dosing was done in a masked fashion.

\section{FFA and Image Analysis for CNV Lesions in Mice}

Analysis of the CNV was performed as described. ${ }^{39,40}$ Briefly, the pupils of mice were dilated with $2.5 \%$ phenylephrine hydrochloride and $1 \%$ tropicamide, then $2 \%$ fluorescein sodium (at $10 \mathrm{~mL} / \mathrm{kg}$ body weight) diluted in water was administered by i.p. injection. Fluorescein angiograms were captured using a Kowa Genesis-Df fundus camera (Kowa,
Tokyo, Japan) at early (90 seconds after fluorescein injection) and late (7 minutes after injection) phases of dye transit. At the early phase, the CNV tissue was clearly defined by the intravascular fluorescein dye, whereas at the late phase, extravascular fluorescein was evident as patches of hyperfluorescence. To determine the number of spontaneous CNV lesions per eye in the JR5558 mice, early-phase FFA images with the best coverage of the posterior pole (with optic disk at the center) were used. Image J version 1.48 (NIH, Bethesda, $\mathrm{MD}$; http://imagej.nih.gov/ij) was used to quantify CNV area by measuring the areas of hyperfluorescence in late-phase FFA images, which correlate well with CNV area according to immunohistologic analysis. ${ }^{39,40}$ Animals were excluded for FFA analysis if a clear image of the retina could not be obtained, for example, because of cataracts. All FFA image analyses were performed by trained investigators who were masked to the identity of the treatment groups.

\section{Immunohistologic Analysis of Eye from Mice}

Eyes were enucleated and fixed with $4 \%$ paraformaldehyde in PBS for 3 hours at $4^{\circ} \mathrm{C}$. To generate eye sections, the cornea and lens were removed after fixation, and the resulting eye cups with retina were cryoprotected in $30 \%$ sucrose in PBS overnight at $4^{\circ} \mathrm{C}$ and were snap-frozen in optimum cutting temperature compound (TissueTek; Sakura Finetek, Torrance, CA), and cryostat sections $(10 \mu \mathrm{m})$ were thaw-mounted onto glass slides. Eyecups whole-mounted without the retina and eyecup sections with the retina were blocked in buffer containing 0.3\% Triton X-100 and 5\% fetal bovine serum in PBS (blocking buffer) for 1 hour at room temperature, then incubated overnight at $4{ }^{\circ} \mathrm{C}$ with fluorescein isothiocyanate-isolectin B4 (dilution 1:300; Vector, Burlingame, CA) alone or in combination with primary antibodies (all at dilution 1:100), namely anti-F4/80 (Abcam), anti-TLR2 (Abcam), anti-Ezrin (07130; Thermo Fisher, Pittsburgh, PA), or anti-NF- $\kappa$ B p65 (Cell Signaling). After three washes, appropriate secondary antibodies, including anti-rat Alexa Fluor 594, anti-goat Alexa Fluor 594, anti-rabbit Alexa Fluor 488, and anti-rabbit Alexa Fluor 594 (all dilution 1:300; Life Technologies, Waltham MA) were added, and specimens were incubated at room temperature for 2 hours. Nuclei were stained with DAPI (Life Technologies). After five washes, the specimens were mounted in 50\% glycerol, 50\% PBS, and $0.04 \%$ sodium azide and viewed by epifluorescence (Olympus BX51 microscope; Olympus, Essex, UK) with a Retina SRV camera (QImaging, Surrey, BC, Canada) with the following objectives and numerical apertures: $4 \times, 0.16$; $10 \times, 0.40 ; 20 \times, 0.75 ; 40 \times, 0.90 ; 60 \times, 1.35$ (oil), and ImagePro 6.2 (Media Cybernetics, Rockville, MD) was used for image acquisition, or an Axioskop 2 Mot Plus microscope (Carl Zeiss, Inc.) equipped with an Axiocam MRm monochrome color camera (Carl Zeiss Inc.), and Axiovision 4.9.1 (Carl Zeiss Inc.) was used for image acquisition. 


\section{Real-Time PCR}

Mouse eyes were stored in RNAlater (Invitrogen, Grand Island, NY) until RNA was extracted from the retina and the RPE/choroid complex using the RNeasy mini kit (Qiagen, Valencia, CA). For experiments using human fetal RPE (hfRPE) cells, total RNA was extracted from cells after indicated treatments using the RNAeasy mini kit (Qiagen). Complementary DNA synthesis was performed using the iSCRIPT kit (Bio-Rad, Hercules, CA), according to the manufacturer's specifications. For real-time PCR, reactions were performed on the LightCycler 480 II (Roche, Indianapolis, IN) or a Realplex ${ }^{2}$ real-time PCR machine (Eppendorf, Hauppauge, NY) using $0.5 \mu \mathrm{mol} / \mathrm{L}$ primers and Faststart Universal SYBR Green PCR Master Mix (Applied Biosystems, Grand Island, NY). Relative gene expression was determined using the $\Delta-\Delta$-Ct method after normalizing sample loading with the housekeeping gene HPRT1. The primer sequences are listed in Table 1.

\section{Isolation and Culture of Primary Human Fetal RPE Cells}

Human fetal eyes were obtained from Advanced Bioscience Resources, Inc. (Alameda, CA) or Novogenix Laboratories, LLC (Los Angeles, CA). Tissues with a gestational age of 15 to 20 weeks were used. The tissue was harvested within 2 hours of death and kept on ice. The eyes were shipped the same day and processed the day of arrival. The time from death to tissue processing was $24 \pm 4$ hours.

RPE isolation and culture were performed according to published methods. ${ }^{42}$ Briefly, intact eye globes were rinsed in antibiotic-antimycotic solution (diluted to $10 \times$; Invitrogen) for 5 minutes. Antibiotics were rinsed off with PBS, and the eyes were transferred to a $10-\mathrm{cm}$ petri dish coated with Sylgard-184 (Dow Corning, Midland, MI) and filled

Table 1 Primer Sequences for Real-Time PCR

\begin{tabular}{|c|c|}
\hline Primer name & Sequence \\
\hline Human HPRT1 & $\begin{array}{l}\text { F: 5'-CCTGGCGTCGTGATTAGTGAT-3' } \\
\text { R: 5'-AGACGTTCAGTCCTGTCCATAA-3' }\end{array}$ \\
\hline Human TLR2 & $\begin{array}{l}\text { F: 5'-TGGTAGTTGTGGGTTGAAGC-3' } \\
\text { R: 5'-GACAGAGAAGCCTGATTGGAG-3' }\end{array}$ \\
\hline Human $I L 1 B$ & $\begin{array}{l}\text { F: 5'-ATGCACCTGTACGATCACTG-3' } \\
\text { R: } 5^{\prime}-\text { ACAAAGGACATGGAGAACACC-3' }\end{array}$ \\
\hline Human IL6 & $\begin{array}{l}\text { F: 5'-CAACCTGAACCTTCCAAAGATG-3' } \\
\text { R: } 5^{\prime}-\text { - } C \text { 'TCAAACTCCAAAAGACCAG-3' }\end{array}$ \\
\hline Human CXCL8 & $\begin{array}{l}\text { F: 5'-AGAAACCACCGGAAGGAACCATCT-3' } \\
\text { R: 5'-AGAGCTGCAGAAATCAGGAAGGCT-3' }\end{array}$ \\
\hline Human $M C P 1$ & $\begin{array}{l}\text { F: 5'-TGTCCCAAAGAAGCTGTGATC-3' } \\
\text { R: 5'-ATTCTTGGGTTGTGGAGTGAG-3' }\end{array}$ \\
\hline Human VEGFA & $\begin{array}{l}\text { F: 5'-GGGCAGAATCATCACGAAGTG-3' } \\
\text { R: 5'-ATTGGATGGCAGTAGCTGCG-3' }\end{array}$ \\
\hline Mouse Hprt1 & $\begin{array}{l}\text { F: 5'-TCAGTCAACGGGGGACATAAA-3' } \\
\text { R: 5'-GGGGCTGTACTGCTTAACCAG-3' }\end{array}$ \\
\hline Mouse Tlr2 & $\begin{array}{l}\text { F: 5'-CCAGAAGCATCACATGACAGA-3' } \\
\text { R: 5'-CAACTTACCGAAACCTCAGACA-3' }\end{array}$ \\
\hline
\end{tabular}

$F$, forward; $R$, reverse with 5\% Miller medium. Excess muscle and connective tissues were removed from around the eyes, then the eyes were bisected at one-third the distance from the eye equator to the anterior surface. Before separation of the anterior segment of the eye, the vitreous body was cut to avoid detaching the retina from the RPE. The eyecups were then incubated with dispase-I solution $(2 \mathrm{U} / \mathrm{mL}$; Roche Diagnostics, Indianapolis, IN) in 5\% Miller medium for 45 minutes at $37^{\circ} \mathrm{C}$, transferred to a petri dish filled with $5 \%$ Miller medium, fixed with 27-gauge needles in the silicon padding and dissected into quadrants. The retinas were gently removed with fine forceps, and RPE-Bruch's membrane samples were collected directly into a cold trypsin-EDTA solution. After incubation at $37^{\circ} \mathrm{C}$ for 15 minutes, the samples were vigorously shaken to separate the RPE cells from the Bruch's membrane. The cells were pelleted (1300 rpm, 4 minutes), suspended in Miller
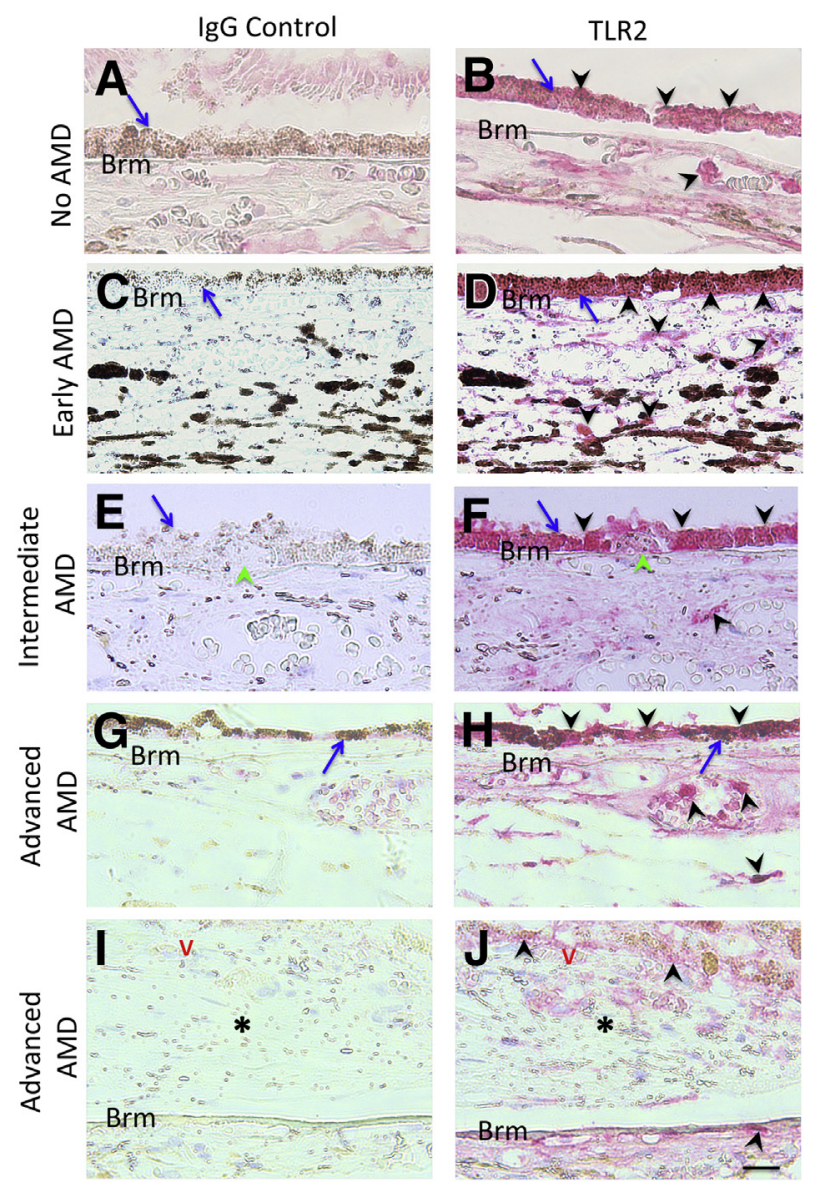

Figure 1 Expression of Toll-like receptor 2 (TLR2; red) in the retinal pigment epithelium (RPE)/choroid area of aged eyes ( $\geq 77$ years) without age-related macular degeneration (AMD) and with different stages of AMD. Aged eye (77 years) without AMD (A and B), aged eye with early AMD [AgeRelated Eye Disease Study (AREDS) 1] (C and D), aged eye with intermediate stage AMD (AREDS 3) (E and $\mathbf{F}$ ), aged eye with advanced AMD (G-J), showing regions without choroidal neovascularization (CNV) (G and $\mathbf{H})$ and with CNV (I and J) (asterisks). Note the absence of the RPE layer beneath regions with CNV. Arrows indicate RPE; black arrowheads, TLR2-positive staining; green arrowheads, small drusen. Brm, Bruch's membrane; IgG Control, isotype match IgG; V, vessel in CNV. Scale bar $=10 \mu \mathrm{m}(\mathbf{A}-\mathbf{J})$. 
medium with $15 \%$ serum, and seeded onto a tissue culture dish $(35 \mathrm{~mm} \times 10 \mathrm{~mm})$. The medium was replaced after 24 hours with 5\% Miller medium and changed every 2 days. Once cells reached confluence ( 1 to 2 weeks; passage 0 ), they were seeded into Transwell plates (12-mm insert, 400-nm pores; Corning Inc., Corning, NY) that were coated with laminin extracellular matrix (Sigma-Aldrich) at 1.5 to $2.0 \times 10^{5}$ cells/well. Cells at passages 1 to 3 were used for experiments; they were often pigmented and displayed a transepithelial electrical resistance of at least $500 \Omega \cdot \mathrm{cm}^{2}$ (EVOM2 Voltohmmeter; World Precision Instruments, Inc., Sarasota, FL) as described. ${ }^{43}$

The synthetic TLR2 ligand PAM2CSK4, neutralizing anti-TLR2 antibody (MAb-mTLR2), anti-TLR1 antibody (Anti-hTLR1-IgG), anti-TLR6 antibody (Anti-hTLR6$\mathrm{IgG}$ ), and control mIgG1 were obtained from InvivoGen. The high purity $(\geq 98 \%$ based on nuclear magnetic resonance analysis) CEP-dipeptide was obtained from a commercial source as a custom synthesis (Haoyuan
Chemexpress Co., Limited, Shanghai, P.R. China). C. pneumoniae (gamma-irradiation inactivated bacteria from cell lysate) was obtained from Meridian Life Science, Inc. (R02620, Memphis, TN).

\section{Statistical Analysis}

For the JR5558 spontaneous CNV model, total CNV area per eye and number of CNV lesions per eye were quantified using FFA, and each individual eye was analyzed as an individual data point $(n)$. Data from FFA were analyzed using one-way analysis of variance followed by a Dunnett's post hoc test to compare the different test groups and dosages with either the control (IgG) or the single treatment group (anti-VEGFR2 at $4.8 \mu \mathrm{g}$ ) as indicated (GraphPad Prism). For real-time PCR analysis using hfRPE Transwell culture, each Transwell was analyzed as an individual data point $(n)$. For real-time PCR analysis using eye tissues, each individual eye was analyzed as an individual data point $(n)$. PCR data were analyzed using
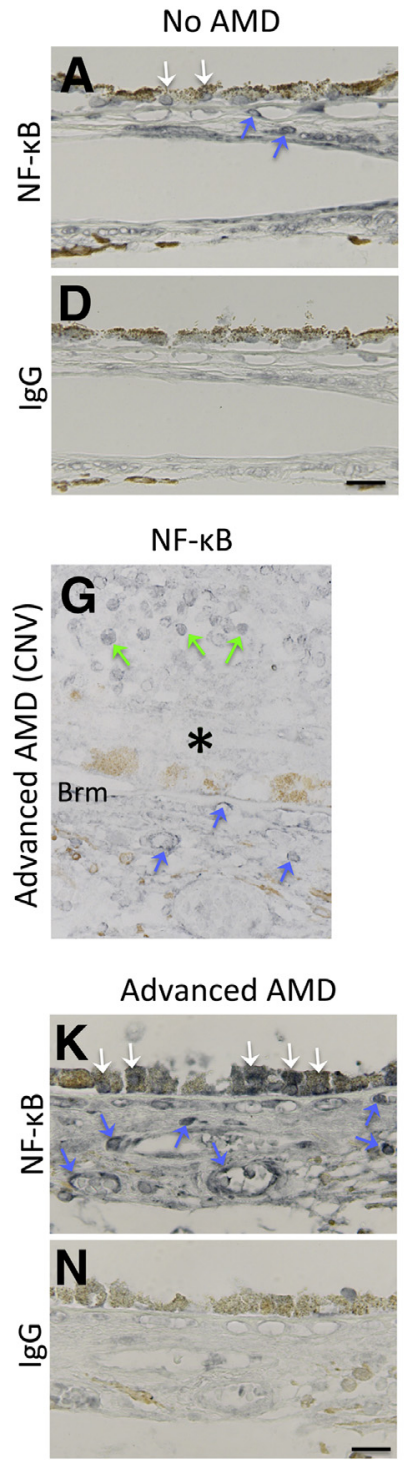
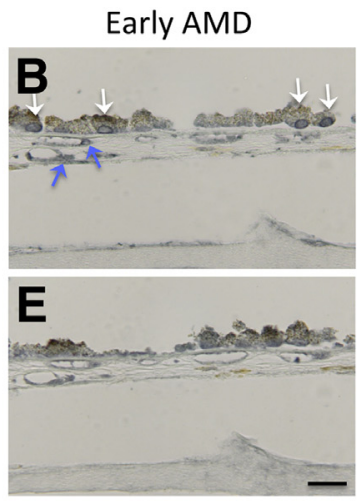

IgG

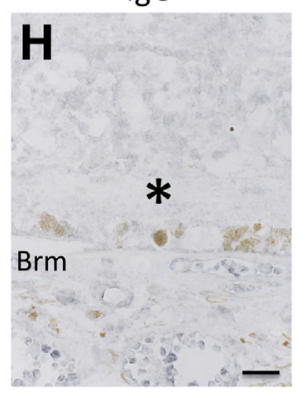

Advanced AMD
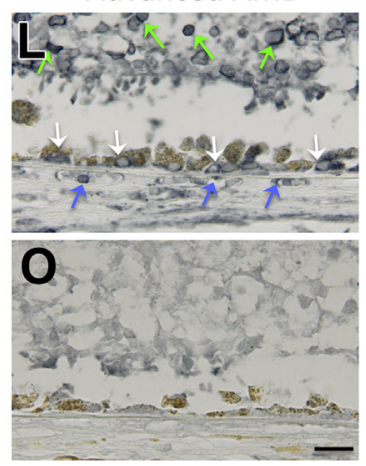

Intermediate AMD
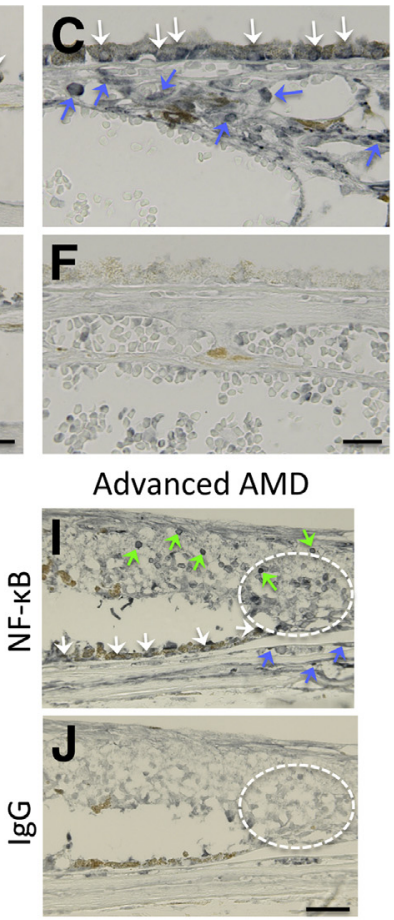

Advanced AMD
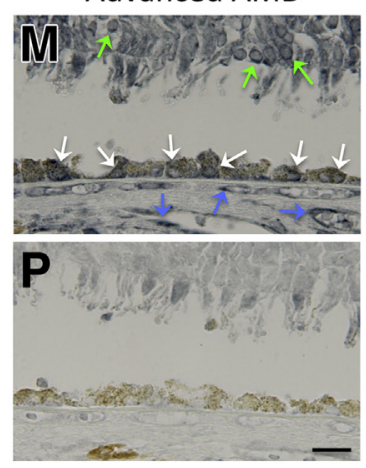

Figure 2 Activation of NF- $\kappa B$ in the retinal pigment epithelium (RPE) during age-related macular degeneration (AMD) pathogenesis. A, B, D, and E: In aged eyes without any signs of AMD and with early AMD ( $\geq 77$ years), only a few RPE cells display nuclear localization of NF- $\kappa B$ (white arrows). Cells with nuclear NF-KB staining in the choroid of the eyes with no AMD and with early AMD may be vascular endothelial cells and inflammatory cells (blue arrows). C and F-P: In aged eyes with intermediate AMD and advanced AMD ( $\geq 77$ years), nuclear localization of NF- $\kappa B$ is detected in many RPE cells (white arrows). In the CNV membrane (asterisks), staining for nuclear NF- $\kappa B$ is unremarkable and limited to a few cells in the retina (green arrows) and choroid (blue arrows) ( $\mathbf{G}$ and $\mathbf{H}$ ). RPE cells with activated NF- $\kappa B$ are detected near the transition zone with geographic atrophy (dashed ovals) (I and J). NF$\kappa \mathrm{B}$-positive cells in the retina (green arrows) are likely to be inflammatory cells because of their rounded nuclear morphologic structure. More nuclear NF- $\kappa \mathrm{B}$ staining in choroidal cells is detected in eyes with intermediate AMD and advanced AMD (blue arrows). Scale bars: $20 \mu \mathrm{m}(\mathbf{A}-\mathbf{H}$ and $\mathbf{K}-\mathbf{P})$; $50 \mu \mathrm{m}$ (I and J). Brm, Bruch's membrane; CNV, choroidal neovascularization. 
one-way analysis of variance, followed by a Turkey post hoc test to compare between different test groups as indicated (GraphPad Prism). For all comparisons, values of $P<0.05$ were considered statistically significant. Data are expressed as means \pm SEM unless otherwise noted. All experiments and data analysis for both animal and cell-based experiments were performed in a masked fashion, and sample size was determined according to prior pilot experiments using the same models.

\section{Results}

TLR2 Is Highly Expressed by the RPE in Human Eyes with and without AMD

In light of the evidence for inflammation as a contributor to AMD and the critical role of TLR2 in modulating oxidative stress-induced angiogenesis in a wound-healing model, ${ }^{31,32}$ we investigated the expression of TLR2 in CNV associated with AMD. Robust expression of TLR2 was detected in the RPE at all stages of AMD and in the RPE of control eyes with no signs of AMD (Figure 1). Some TLR2-positive endothelial cells and/or leukocytes associated with the vessels were also observed in the choroid, and sometimes a few pigmented cells (likely RPE) within the CNV membrane were positive for TLR2 staining (Figure 1), but, interestingly, the CNV membrane (including the vessels) was only weakly stained or negative for TLR2 expression. Weak TLR2 staining was also detected on drusen (Figure 1). These data suggested that RPE cells normally express high levels of TLR2 and that the RPE continue to express TLR2 at different stages of AMD.

\section{RPE Cells Display Greater Nuclear Localization of the TLR2 Target NF- $\kappa B$ during Intermediate and Late Stages of Human AMD}

We used immunohistologic analysis of clinical specimens to examine nuclear localization of $\mathrm{NF}-\kappa \mathrm{B}$, a major downstream
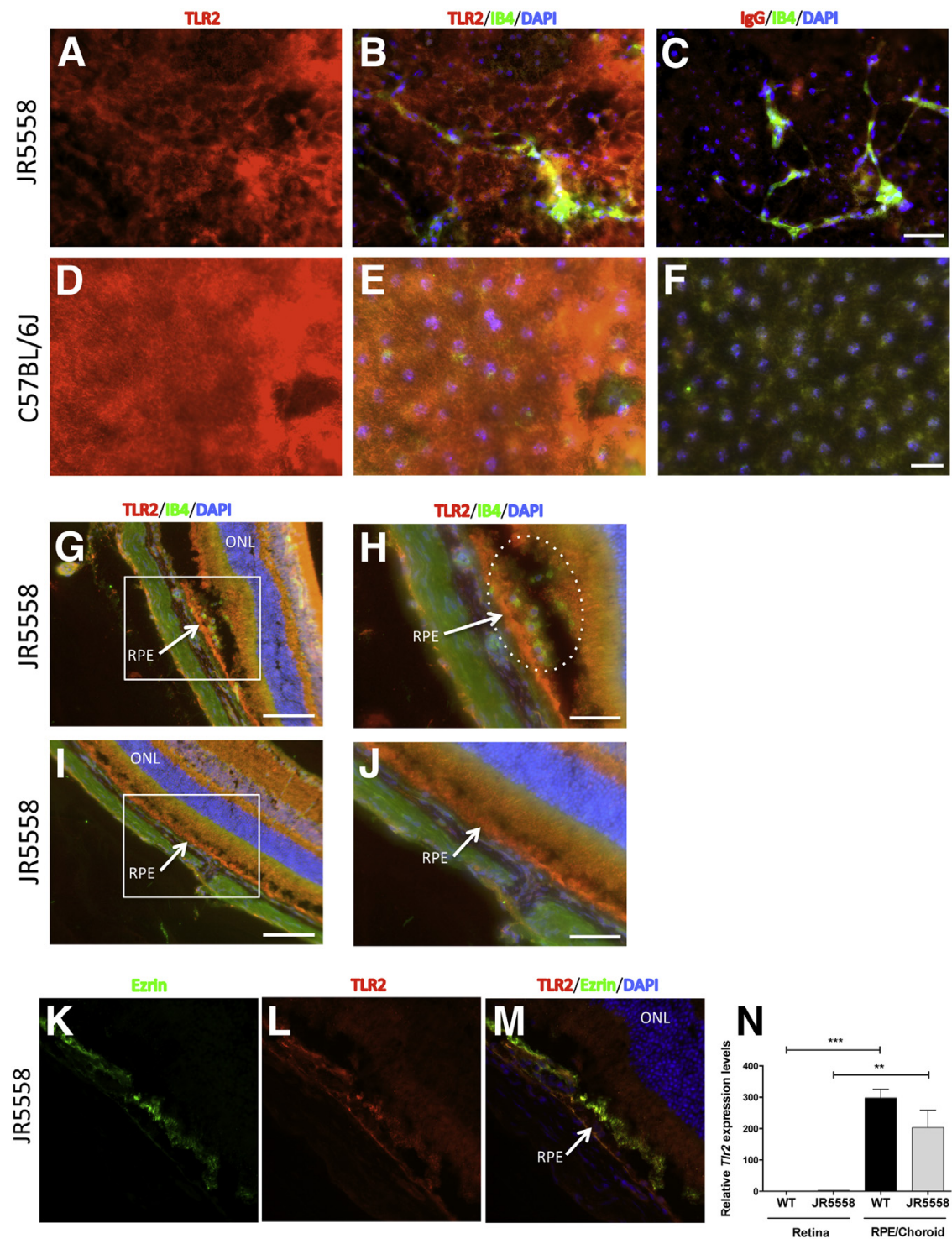

Figure 3 Expression of Toll-like receptor 2 (TLR2) in the retinal pigment epithelium (RPE) of wild-type $\mathrm{C} 57 \mathrm{BL} / 6 \mathrm{~J}$ and JR5558 spontaneous choroidal neovascularization (CNV) mice. A-F: $E n$ face view of whole-mount eyecups (with the retinae removed). Staining shows robust TLR2 expression (red) on the RPE both around and at a distance from the CNV vessels [isolectin B4 (IB4); green], whereas little TLR2 staining of CNV vessels (IB4; green) is detected in the JR5558 mice $(\mathbf{A}-\mathbf{C})$. In the whole-mount eyecups from wild-type $\mathrm{C} 57 \mathrm{BL} / 6 \mathrm{~J}$ mice, strong TLR2 expression is detected on the RPE (D-F ). G-J: In eye sections from JR5558 mice, expression of TLR2 is detected readily on the apical side of the RPE layer, whereas the CNV vessels (dotted oval) are largely negative for TLR2 expression (H). $\mathbf{G}$ and $\mathbf{H}$ are from a region with CNV, whereas $\mathbf{I}$ and $\mathbf{J}$ are from a CNV-free region. $\mathbf{H}$ and $\mathbf{J}$ are higher magnification images of the boxed areas in $\mathbf{G}$ and I, respectively. $\mathbf{K}-\mathbf{M}$ : Double immunostaining of eye sections from JR5558 mice reveals colocalization of ezrin (green), a marker for microvilli of RPE, and TLR2 (red) to the apical surface of the RPE layer. N: Semiquantitative real-time PCR for TLR2 mRNA levels in both wild-type C57BL/6J and JR5558 mice, showing significantly higher levels of TLR2 mRNA in the RPE/choroid complex than in the retina. Data are expressed as means \pm SEM. ${ }^{* *} P<0.01,{ }^{* * *} P<0.001$ (one-way analysis of variance). Scale bars: $50 \mu \mathrm{m}(\mathbf{A}-\mathbf{C}, \mathbf{H}$, and $\mathbf{J}-\mathbf{M})$; $20 \mu \mathrm{m}(\mathbf{D}-\mathbf{F}) ; 100 \mu \mathrm{m}$ (G and I). ONL, outer nuclear layer of the photoreceptors; WT, wild-type. 
target of the TLR2 pathway, as an indicator of TLR2 activation. Nuclear localization of NF- $\mathrm{KB}$ was detected in a small number of RPE cells in aged eyes without any signs of AMD and with early AMD, corresponding to Age-Related Eye Disease Study 1. Greater numbers of RPE cells displaying nuclear translocation of NF- $\kappa \mathrm{B}$ were observed in RPE cells in aged eyes with intermediate AMD, corresponding to Age-Related Eye Disease Study 3, and advanced AMD (Figure 2). Activation of NF- $\kappa \mathrm{B}$ was detected in some cells in the choroid, likely endothelial cells of the choroidal vessels and resident leukocytes (Figure 2), a pattern similar to that observed for TLR2 (Figure 1). Interestingly, in the CNV membrane and in the adjacent retina, nuclear staining of NF- $\mathrm{BB}$ was mostly detected in cells with small rounded nuclei (Figure 2). These were likely infiltrated inflammatory cells, because vascular endothelial cells often have elongated nuclei (Figure 2). The lack of nuclear NF- $\mathrm{BB}$ in the CNV membrane (Figure 2) matched the lack of TLR2 expression in the CNV lesion (Figure 1).

\section{TLR2 Is Highly Expressed by the RPE in Mouse Eyes} with and without CNV

To investigate the role of TLR2 in the pathogenesis of CNV, the JR5558 mouse, an established model of spontaneous $\mathrm{CNV},{ }^{39,40}$ was used. As with the human eyes, the RPE cells in close proximity to and distant from the CNV lesion were positive for TLR2 staining (Figure 3). RPE cells in the wildtype control mouse, too, stained positive for TLR2 (Figure 3, D-F). TLR2 was localized to the apical side of the RPE (Figure 3, G-J), where it colocalized with ezrin, a marker for RPE microvilli (Figure 3, K-M). The vessels of the spontaneous CNV were mostly negative for TLR2 staining, although some cells that tightly associated with the CNV vessels, likely leukocytes and/or microglia, were positive for TLR2 (Figure 3, A-C). Immunostaining of the eye sections confirmed the lack of TLR2 staining in CNV vessels (Figure 3, $\mathrm{G}$ and $\mathrm{H}$ ).

With the use of semiquantitative reverse transcription and real-time quantitative PCR analysis, significantly higher expression levels of Tlr2 mRNA were detected in the RPE/ choroid complex than in the retina from both the wild-type C57BL/6J and the JR5558 mice (Figure 3N). Taken together, these results suggested that the primary source of TLR2 in the eye is the RPE, both in normal eyes and in eyes with CNV.

\section{TLR2 Plays a Functional Role in CNV Development}

To determine the function of TLR2 in the development of $\mathrm{CNV}$, including the initiation and growth of the CNV lesion, different doses $(0.8,1.6$, and $3.2 \mu \mathrm{g}$ per injection per eye) of TLR2-neutralizing antibody were delivered via a single intravitreal injection into the eyes of JR5558 mice, then the effect on CNV was analyzed by FFA 7 days after injection. All three doses of anti-TLR2 antibody
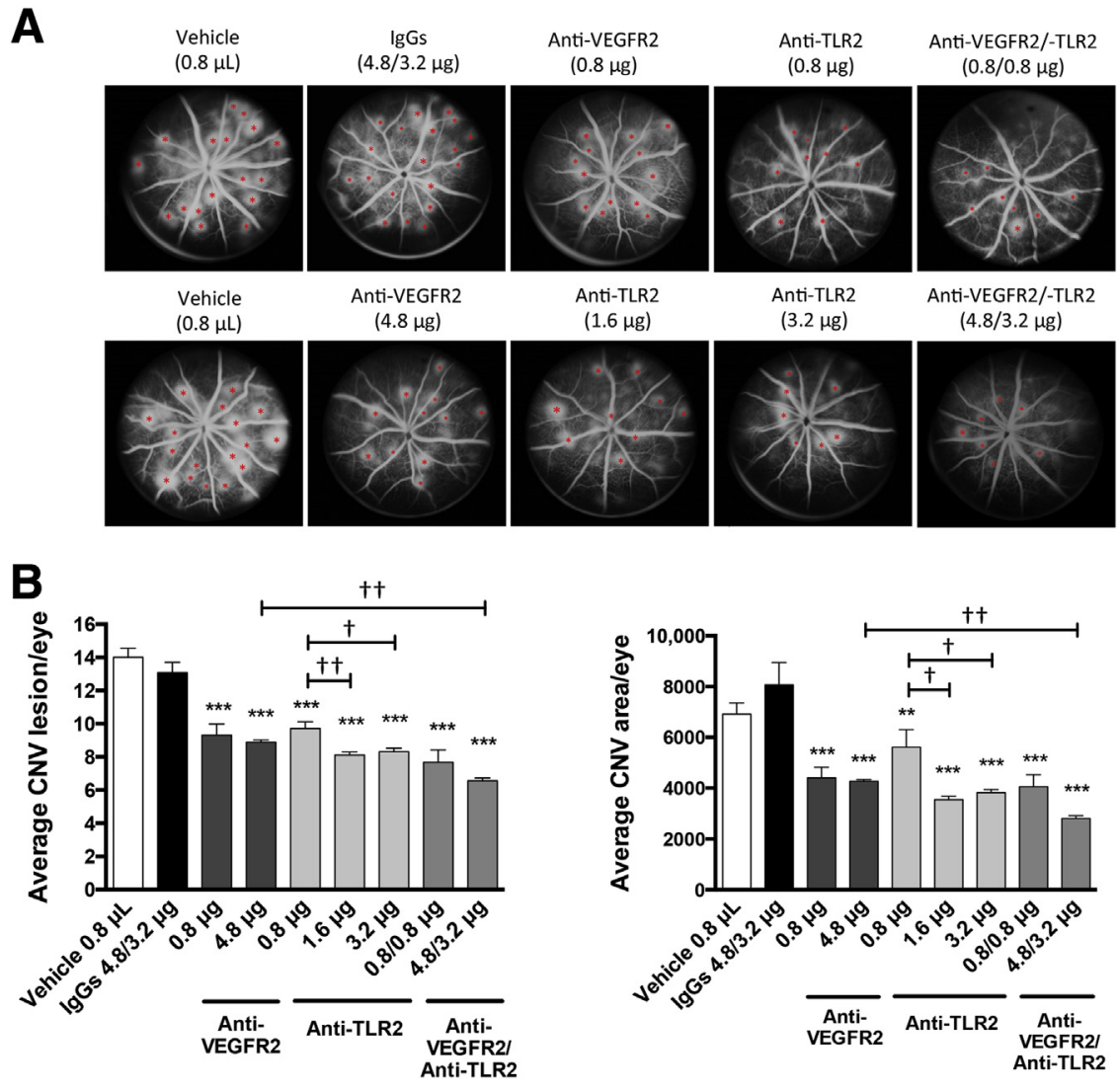

Figure 4 Intravitreal anti-Toll-like receptor 2 (TLR2) neutralizing antibody significantly suppresses spontaneous choroidal neovascularization (CNV) initiation and growth. A: Representative fundus fluorescein angiography (FFA) images showing the CNV lesions (hyperfluorescent spots; asterisks) in different treatment groups. Note the substantial reduction in the number of CNV lesions in the anti-vascular endothelial growth factor receptor 2 (VEGFR2) and anti-TLR2 combination treatment groups. B: Quantification of the FFA data from $\mathbf{A}$, showing a significant reduction in the average number of CNV lesions per eye and the average CNV area per eye in the anti-VEGFR2 groups and the anti-TLR2 groups, both as individual treatment and as combination treatment. $\mathrm{IgGs}=$ rat IgG2A at $4.8 \mu \mathrm{g}$ and mouse IgG1 at $3.2 \mu \mathrm{g}$ per injection. Data are expressed as means \pm SEM. $n=12$ to 33 eyes. ${ }^{*} P<0.01$, $* * * P<0.001$ versus IgG control-treated group (one-way analysis of variance); ${ }^{\dagger} P<0.05$, ${ }^{\dagger \dagger} P<0.01$ (one-way analysis of variance). 
significantly suppressed the formation of $\mathrm{CNV}$, with an efficacy that was similar to that of VEGFR2 neutralization (0.8 and $4.8 \mu \mathrm{g}$ per intravitreal injection per eye) (Figure 4). The higher doses of anti-TLR2 antibody (1.6 and $3.2 \mu \mathrm{g})$ were significantly more effective in reducing the area of CNV per eye compared with the lower dose $(0.8 \mu \mathrm{g})$, indicating a dose response for the anti-TLR2 antibody in reducing $\mathrm{CNV}$ development in this model (Figure 4). No significant dose effect was observed for the anti-VEGFR2 antibody, suggesting that the $0.8-\mu \mathrm{g}$ intravitreal dose was already achieving maximal inhibition.

As expected, combination treatment with anti-VEGFR2 and anti-TLR2 antibodies resulted in significant inhibition of the number of CNV lesions per eye and CNV area per eye compared with the IgG control. Interestingly, the high-dose combination treatment ( $4.8 \mu \mathrm{g}$ of anti-VEGFR 2 and $3.2 \mu \mathrm{g}$ of anti-TLR2) was significantly better than the high-dose treatment with anti-VEGFR2 alone $(4.8 \mu \mathrm{g})$ for reducing the number of $\mathrm{CNV}$ lesion per eye and in reducing average $\mathrm{CNV}$ area per eye (Figure 4). No significant difference was detected between other combination treatment groups and the antiVEGFR2 treatment groups. These results suggested an additive suppressive effect for antagonism of VEGFR2 and TLR2 on the development of spontaneous CNV, and that the VEGFR2 and TLR2 pathways may have nonoverlapping function during $\mathrm{CNV}$ pathogenesis.

\section{TLR2 Promotes Macrophage Recruitment to the CNV}

Because macrophage recruitment to sites of CNV played a significant role in pathologic vessel development in the
JR5558 mice, ${ }^{40}$ the eyes from animals treated with antibodies against VEGFR2 and/or TLR2 were examined by immunohistochemistry to determine the morphologic structure of the CNV vessels and the degree of macrophage association with the CNV. Although there were no obvious morphologic differences between the CNV vessels in eyes treated with anti-VEGFR2 and/or anti-TLR2 and those treated with vehicle, the levels of staining for macrophages associated with the CNV were dramatically lower in eyes treated with anti-TLR2 alone or anti-TLR2 in combination with anti-VEGFR2 (Figure 5). Anti-VEGFR2 treatment alone was effective in inhibiting CNV development (Figure 4), but this treatment had no detectable effect on the degree of $\mathrm{CNV}$-associated macrophages (Figure 5). These data suggested that TLR2 activation in the RPE promoted recruitment of macrophages during $\mathrm{CNV}$ and that this effect was independent of that of the VEGF/ VEGFR2 pathway.

\section{Activation of TLR2 Promotes Expression of Proinflammatory Cytokines by the RPE}

To determine why TLR2 antagonism was effective in inhibiting spontaneous CNV development and, in particular, macrophage recruitment to the $\mathrm{CNV}$, we determined the effect of TLR2 activation on RPE cells in vitro. Cultured hfRPE expressed TLR1, TLR2, TLR4, and TLR6 mRNA, albeit at levels significantly lower (2- to 16-fold) than those observed for THP-1 cells (data not shown), a human monocyte cell line known to express high levels of these

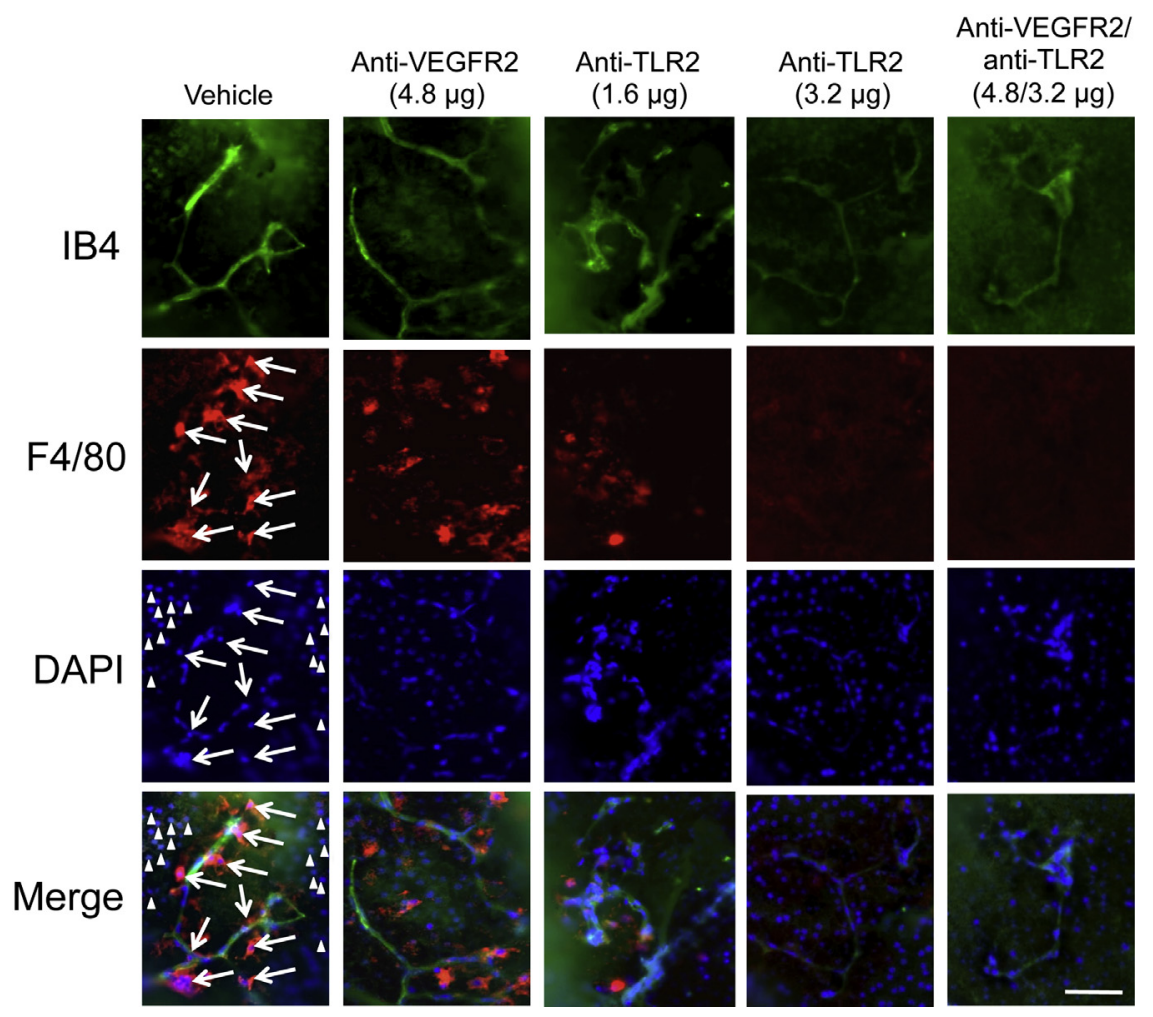

Figure 5 Toll-like receptor 2 (TLR2) antagonism in the eye reduces macrophage association with choroidal neovascularization (CNV) in the JR5558 mouse. Representative images of macrophage staining using whole-mount eyecups without retinae from all treatment groups. Although both anti-vascular endothelial growth factor receptor 2 (VEGFR2) and anti-TLR2 treatments effectively suppress growth of CNV vessels, only anti-TLR2 treatment reduces the number of $\mathrm{CNV}$-associated macrophages ( $\mathrm{F} 4 / 80$; red) in the eye. Macrophages and their nuclei in the vehicle group are highlighted with arrows, whereas some of the RPE cells and their nuclei are highlighted with arrowheads. Scale bar $=200 \mu \mathrm{m}$. IB4, isolectin B4 vascular staining (green). 
TLRs. ${ }^{44}$ Treatment of hfRPE with a synthetic diacylated lipopeptide TLR ligand, Pam2CSK4, ${ }^{45}$ led to robust induction of the mRNA for proinflammatory cytokines IL-6, monocyte chemoattractant protein 1 [MCP1/chemokine (C-C motif) ligand 2 (CCL2)], CXCL8/IL-8, IL-1 $\beta$, and TLR2 itself. Neutralizing antibody against TLR2 significantly blocked the increase in cytokines/TLR2 expression induced by Pam2CSK4 (Figure 6A). The degree of upregulation was variable, likely in part because of different isolates of hfRPE had different baseline levels of expression for these proinflammatory genes, but significant induction was observed in all hfRPE isolates tested (Figure 6).

To determine whether other TLRs contributed to the Pam2CSK4-induced expression of proinflammatory genes, for example, via hetero-dimerization with TLR2, neutralizing antibodies against TLR1 and TLR6 were tested both alone and in combination with anti-TLR2 antibody. Only anti-TLR2 neutralizing antibodies were effective in inhibiting Pam2CSK4-induced up-regulation of $I L 1 B, I L 6$, and TLR2 in our system (Figure 6B).
End Products of Lipid 0xidation Enhance TLR2Mediated Expression of Proinflammatory Genes in RPE

We next identified a pathologically relevant ligand that could mediate TLR2 activation in the RPE during AMD pathogenesis. The aged RPE was exposed to high oxidative stress in the lipid-rich microenvironment of the retina and, during $\mathrm{AMD}$, in drusen deposits. End products of lipid oxidation, including CEP adducts, could directly activate TLR2 and promote angiogenesis. ${ }^{31,32}$ We therefore tested the effect of CEP on TLR2 activation in RPE cells.

Primary hfRPE cells were treated with different doses of Pam2CSK 4 and CEP, both alone and in combination, and expression of proinflammatory genes was assessed by realtime quantitative PCR. CEP alone did not induce expression of proinflammatory cytokines or chemokines in the hfRPE (Figure 7), even at doses up to $52.4 \mu \mathrm{mol} / \mathrm{L}$ and duration of treatment of up to 72 hours (data not shown). However, addition of CEP to Pam2CSK4 significantly enhanced expression of $I L 6, M C P 1, C X C L 8, I L 1 B$, and TLR2 relative
A
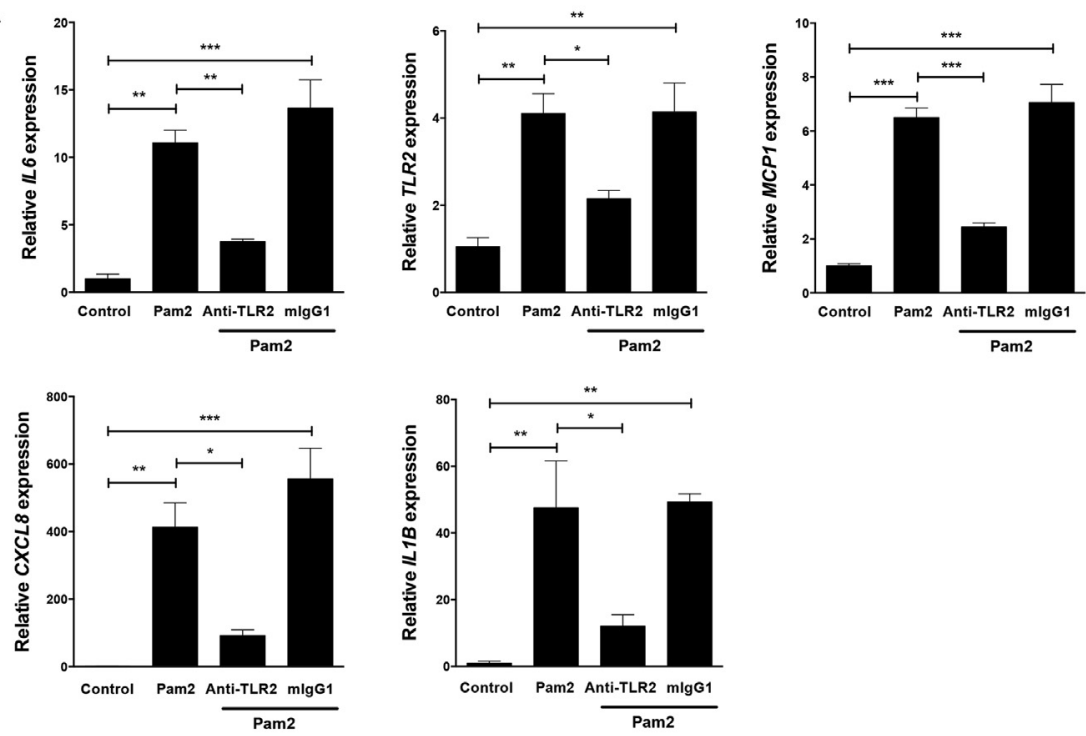

B

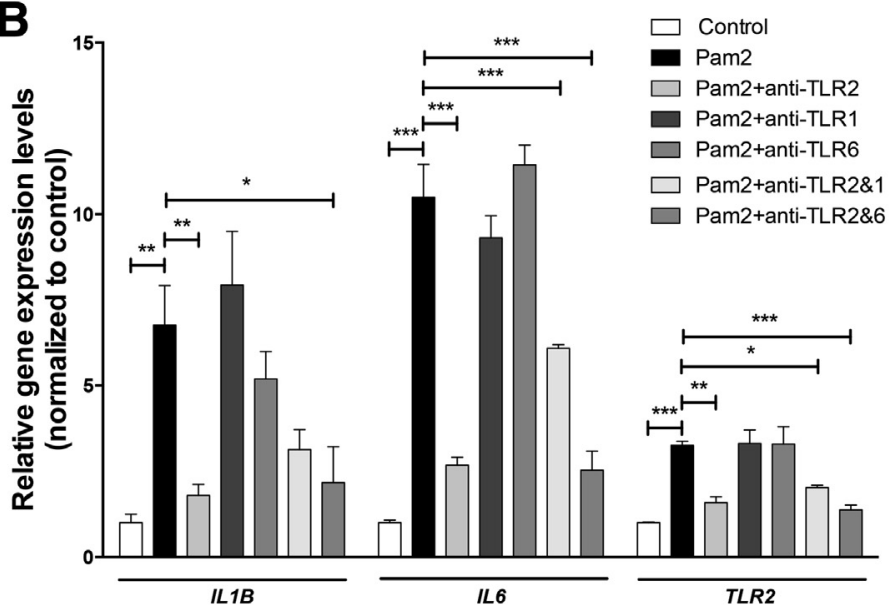

Figure 6 Toll-like receptor 2 (TLR2) mediates expression of proinflammatory genes in primary human retinal pigment epithelium (RPE) cells. A: Pam2CSK4 (Pam2), a synthetic diacylated lipoprotein and TLR2-selective ligand, induces robust expression of IL6, MCP1,CXCL8, IL1B, and TLR2 by primary human RPE cells, an induction that is suppressed by $4 \mu \mathrm{g} / \mathrm{mL}$ TLR2-specific neutralizing antibody. B: Induction of $I L 1 B, I L 6$, and $T L R 2$ expression in human primary RPE cells by Pam2CSK4 is not affected by neutralizing antibodies against TLR1 $(4 \mu \mathrm{g} / \mathrm{mL})$ or TLR6 $(4 \mu \mathrm{g} / \mathrm{mL})$. Note that at least two different donor eyes were used for primary human RPE isolation and culture for this experiment. Data are expressed as means \pm SEM. ${ }^{*} P<0.05,{ }^{*} P<0.01$, and $* * * P<0.001$ (one-way analysis of variance). 

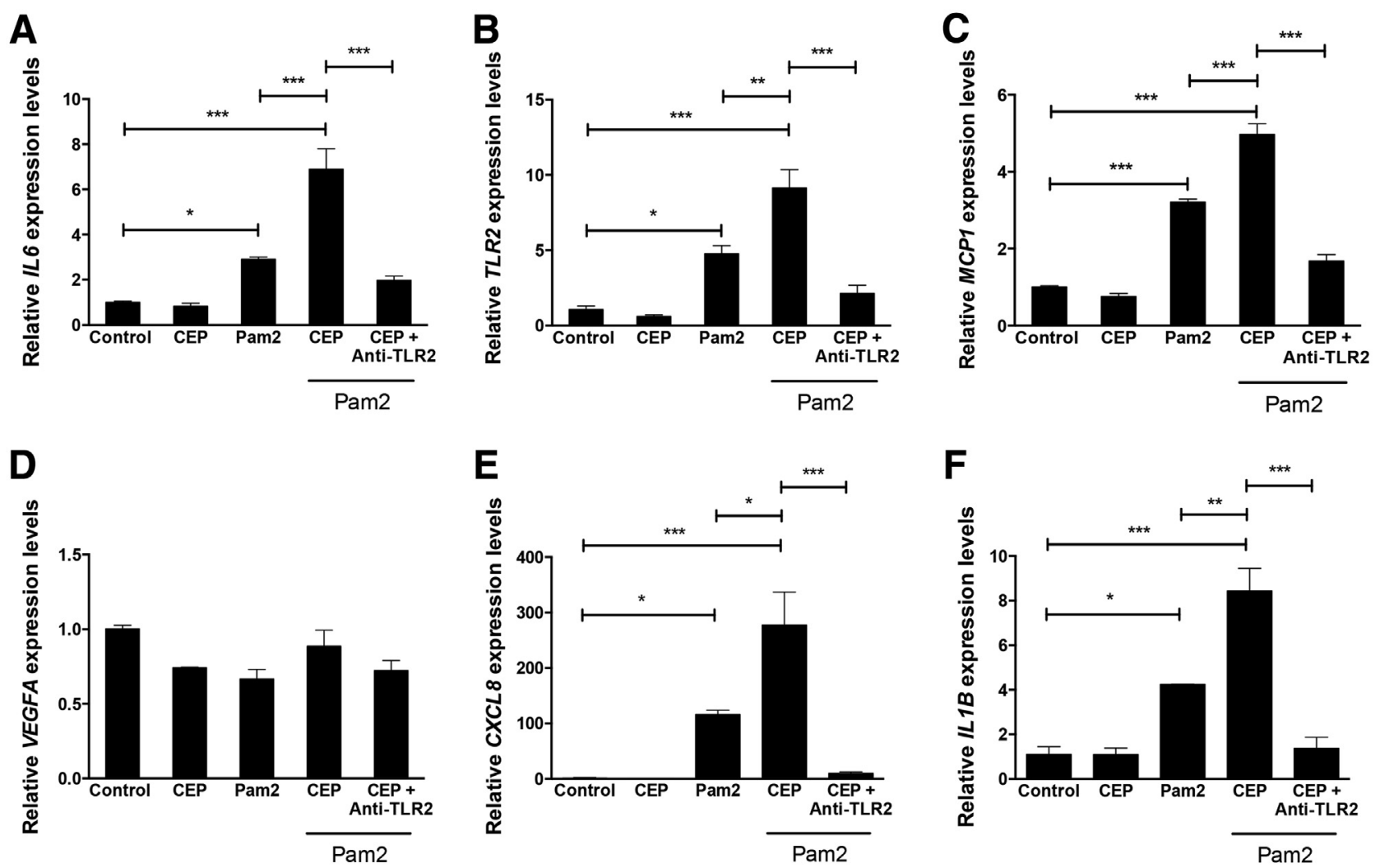

Figure 7 Carboxyethylpyrrole (CEP)-dipeptide has a significant synergistic effect with the Toll-like receptor 2 (TLR2)-selective ligand Pam2CSK4 (Pam2) on inducing expression of proinflammatory genes in human primary retinal pigment epithelium (RPE) cells. A-C, E, and F: CEP alone does not induce the expression of IL6, MCP1, CXCL8, IL1B, or TLR2, whereas Pam2CSK4 significantly induces expression of these genes in human fetal RPE (hfRPE). Combination treatment with CEP and Pam2SCK4 results in a synergistic induction of these proinflammatory genes, and anti-TLR2 neutralizing antibody (4 $\mu \mathrm{g} / \mathrm{mL})$ significantly suppresses the effects of the CEP and Pam2CSK4 combination treatment. D: CEP, Pam2CSK4, and the combination fails to induce VEGFA expression compared with the control in hfRPE cells. Pam2CSK4 at $100 \mathrm{ng} / \mathrm{mL}(78.6 \mathrm{nmol} / \mathrm{L})(\mathbf{A}-\mathbf{D}) ;$ Pam2CSK4 at $50 \mathrm{ng} / \mathrm{mL}(39.3 \mathrm{nmol} / \mathrm{L})(\mathbf{E}$ and F); CEP at $10 \mu \mathrm{g} / \mathrm{mL}$ $(26.2 \mu \mathrm{mol} / \mathrm{L})(\mathbf{A}-\mathbf{F})$. Data are expressed as means \pm SEM. ${ }^{*} P<0.05,{ }^{* *} P<0.01$, and ${ }^{* * *} P<0.001$ (one-way analysis of variance).

to Pam2CSK4 treatment alone (Figure 7, A-C, E, and F). Interestingly, treatment with Pam2CSK4 and CEP, either individually or in combination, did not significantly affect expression of VEGFA (Figure 7D). These data suggested that CEP is not a conventional ligand for TLR2, but rather functioned as a co-stimulatory ligand to potentiate and enhance the activation of TLR2 by conventional ligands such as Pam2CSK4 that regulated expression of proinflammatory genes.

Next, we probed the effect of gamma-irradiation inactivated $C$. pneumoniae $(\mathrm{Cpn}),{ }^{36,38}$ a bacterial strain associated with AMD on TLR2-mediated expression of proinflammatory genes. The effects of Cpn were assessed in the presence or absence of CEP. Combination treatment of hfRPE with Cpn and CEP enhanced expression of $M C P 1$, $C X C L 8$, and $I L I B$ compared with Cpn treatment alone at the 6- and 48-hour time points (Figure 8, B-D and G-I). Induction of IL6 expression by Cpn was also significantly enhanced by CEP treatment at the 48-hour time point (Figure 8, A and F). Treatment with a neutralizing antiTLR2 antibody significantly suppressed induction of the proinflammatory genes by the Cpn and CEP combination treatment, confirming that TLR2 was involved in the response. Again, treatment with Cpn and/or CEP did not significantly increase VEGFA expression in hfRPE compared with untreated controls (Figure 8, E-J). Cpn therefore acted as a ligand for TLR2 in RPE cells, promoting expression of proinflammatory genes, and the activity of TLR2 in this context was enhanced by end products of lipid oxidation.

\section{Discussion}

To validate the functional role of TLR2 in CNV pathogenesis, we examined the expression of TLR2 in clinical specimens and in an animal model of AMD. The finding that RPE cells express high levels of TLR2 on their apical surface is a reflection of RPE function as a barrier, an important role in immune surveillance, as a sensor for various PAMPs and DAMPs in the retina. ${ }^{27,46}$ The increase in nuclear localization of NF- $\mathrm{KB}$ with AMD progression could indicate an increase in TLR2 activation and a possible proinflammatory function for RPE in AMD pathogenesis. As AMD progresses, the RPE cells become atrophic, which would result in a reduction in overall TLR2 levels in the 

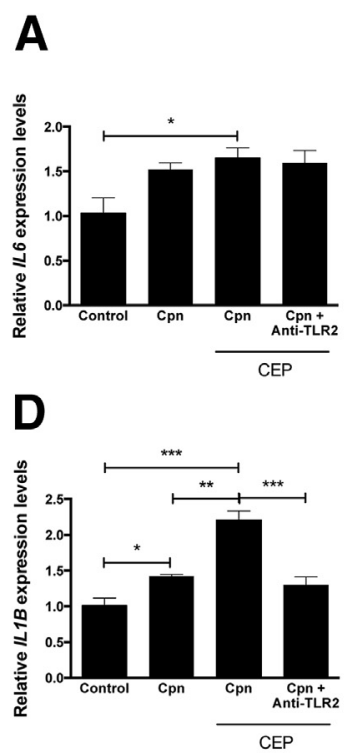

$\mathbf{F}$
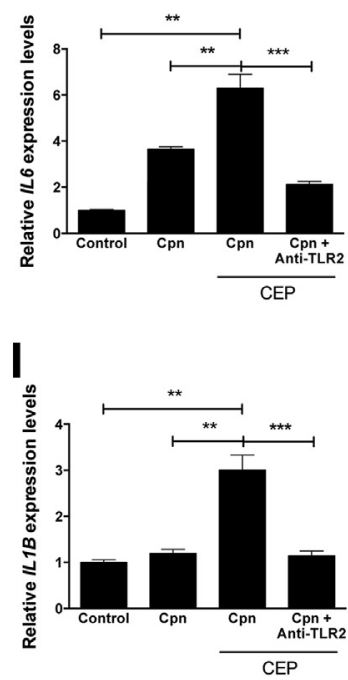
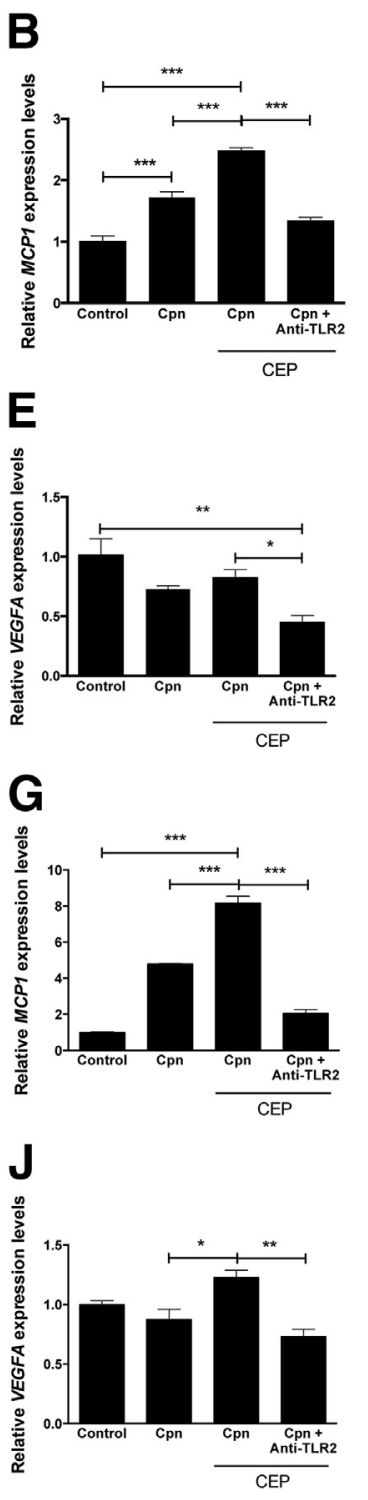
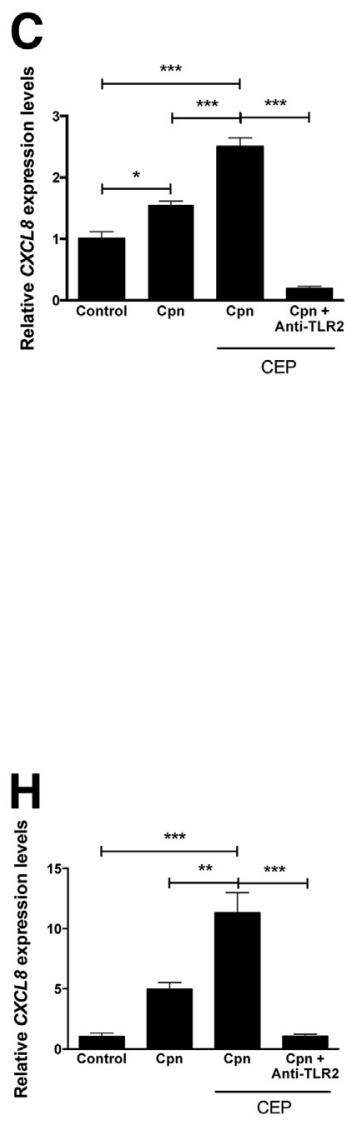

Figure 8 Synergistic effects of carboxyethylpyrrole (CEP)-dipeptide with gamma irradiation-inactivated Chlamydia pneumoniae (Cpn) in inducing Toll-like receptor 2 (TLR2)mediated expression of proinflammatory genes in retinal pigment epithelium (RPE) cells. Primary human fetal RPE (hfRPE) cells were treated with $100 \mu \mathrm{g} / \mathrm{mL}$ Cpn alone or Cpn plus $26.2 \mu \mathrm{mol} / \mathrm{L}$ CEP for either $6(\mathbf{A}-\mathbf{E})$ or $48(\mathbf{F}-\mathbf{J})$ hours. A synergistic effect for IL6 expression is detected at 48 hours, whereas synergistic effects for the expression of $M C P 1, C X C L 8$, and IL1B are detected at both 6 and 48 hours. The induction of expression of proinflammatory genes by treatment with Cpn and CEP is significantly suppressed in the presence of an anti-TLR2 neutralizing antibody $(4 \mu \mathrm{g} / \mathrm{mL})$ (B-D and $\mathbf{F}-\mathbf{I})$. Treatment with $\mathrm{Cpn}$ either alone or in combination with CEP does not induce VEGFA expression in hfRPE at 6 or 48 hours compared with control. Anti-TLR2 antibody significantly suppresses background vascular endothelial growth factor (VEGF) expression in the control group at 6 hours and in the group treatment with Cpn plus CEP at 48 hours (E and $\mathbf{J}$ ). Data are expressed as means \pm SEM. ${ }^{*} P<0.05$, $* * P<0.01$, and ${ }^{* * *} P<0.001$ (one-way analysis of variance). eye, due to the loss of RPE. This is consistent with our observation of lower TLR2 staining levels because of RPE loss in the clinical samples with advanced AMD (CNV) compared with eyes with earlier stage AMD or without AMD. This finding is also consistent with the data from the mouse model of spontaneous $\mathrm{CNV}$, in which the levels of TLR2 gene expression by the RPE/choroid complex tended to be lower than those for age-matched, wild-type controls, although this difference was not statistically significant.

Although some TLR2-positive cells were detected in the choroid in both the human and mouse eyes, neovessels in the CNV did not express high levels of TLR2. These findings differ from the reports of TLR2 in endothelial cells, in which TLR2 has been implicated in oxidative stressmodulated angiogenesis during wound healing. ${ }^{31}$ This dissimilarity is likely because of the difference in mechanisms of angiogenesis between these two models. We have shown that the spontaneous CNV model is driven by inflammation $^{39-41}$; thus, it may lack certain components of the oxidative stress-mediated wound-healing response, which would include TLR2-expressing endothelial cells. Because TLR2 antagonism effectively inhibited the initiation and growth of spontaneous $\mathrm{CNV}$, it is reasonable to assume that TLR2 activation in the RPE plays an early role in $\mathrm{CNV}$ pathogenesis. The reduction in CNV-associated macrophage investment observed with anti-TLR2 treatment is consistent with this hypothesis, because macrophage recruitment to the $\mathrm{CNV} / \mathrm{RPE}$ is considered to be one of the initial steps that drives $\mathrm{CNV}$ pathogenesis. ${ }^{28}$

It was surprising that the CEP adduct, a known component of drusen that has been associated with AMD pathogenesis, ${ }^{47,48}$ did not directly activate TLR2 in RPE, although it enhanced the effects of both synthetic and bacterial ligands. By enhancing TLR2 activation by other 
ligands, CEP generated during aging could exacerbate the TLR2-mediated inflammatory response in the RPE. It is important to point out that hyperactivation of TLR2 by the synthetic ligand or bacterial ligand in combination with CEP in our cell-based model induced NF- $\kappa \mathrm{B}$ activation but was not sufficient to induce activation of the inflammasome and RPE cell death (data not shown). However, it led to induction of proinflammatory genes including $I L 1 B$, which could represent a priming step necessary for full activation of the inflammasome in the RPE by additional signals, such as oxidative stress or lysosomal destabilization. ${ }^{49}$ Thus, we speculate that $\mathrm{CNV}$ pathogenesis in aging eyes may involve a two-hit process: the first, accumulation of CEP in aging eyes that effectively sensitizes TLR2 for promoting inflammation; the second, activation of TLR2 by DAMPs and/or PAMPs such as infection with bacteria or viruses. This two-step process would trigger hyperactivation of the TLR2 and chronic RPE-mediated inflammation, resulting in tissue damage, subsequent up-regulation of VEGFA, including by the RPE and recruited macrophages, and eventual neovascularization. In support of this concept, $C$. pneumoniae antigen has been detected in clinical samples of $\mathrm{CNV}$ membranes, and human cytomegalovirus infection has been associated with wet AMD. ${ }^{38,50,51}$ If this mechanism is responsible for even a portion of $\mathrm{CNV}$ pathogenesis, treating patients with broad-spectrum antibiotics and/or antiviral drugs to suppress infection at the RPE could inhibit the development of $\mathrm{CNV}$ and represent a novel means of reducing the incidence and/or progression of $\mathrm{CNV}$.

TLR2 antagonism effectively blocked CNV in our mouse model of spontaneous CNV, either when used as a monotherapy or in combination with anti-VEGFR2, suggesting that targeting of TLR2 activation could be an efficacious therapeutic strategy for CNV. Although our studies focus on TLR2, it is well established that other TLRs are expressed by the RPE, and some have been implicated in AMD pathogenesis. ${ }^{26-28,32}$ It will be important to determine whether other TLRs contribute to $\mathrm{CNV}$ pathogenesis by promoting RPE inflammation.

Because TLR2 is highly localized on the apical surface of RPE, ocular delivery of TLR2 antagonist could be an effective route of delivery. Furthermore, because the TLR2-null mice are largely normal and do not display any reported retinal phenotype, ocular TLR2 antagonism for CNV should be relatively safe. ${ }^{36,52}$ TLR2 may therefore serve as a novel therapeutic target for reducing $\mathrm{CNV}$, either as a single therapy or in combination with anti-VEGF therapy for wet AMD.

\section{Acknowledgments}

We thank Shannon Bunker (University College London) for the animal dosing and fundus fluorescein angiography experiments; Magali Saint Geniez, Jared Iacovelli, and Gopalan Gnanaguru [Schepens Eye Research Institute (SERI)] for instruction in culturing primary retinal pigment epithelium; Gianna Teague (SERI) for technical advice for immunohistologic staining; Dr. Gerald Gough and
Dr. Monica Belich for scientific discussion; Dr. Patricia D'Amore for critical reading of the manuscript; and Dr. Anne Goodwin for scientific editing.

L.F., M.J., K.Y.V.L., A.M., M.E., D.I., and R.F. performed the experiments, collected and analyzed the data, and generated the figures; P.A., K.L., and D.S. designed experiments and interpreted data; Y.S.N. conceived the study, designed and performed experiments, and interpreted data, generated figures, and performed literature searches; all authors wrote and approved the manuscript; Y.S.N. is the guarantor of this work and, as such, had full access to all data in the study and takes responsibility for the integrity of the data and the accuracy of the data analysis.

\section{References}

1. Gragoudas ES, Adamis AP, Cunningham ET Jr, Feinsod M, Guyer DR; VEGF Inhibition Study in Ocular Neovascularization Clinical Trial Group: Pegaptanib for neovascular age-related macular degeneration. N Engl J Med 2004, 351:2805-2816

2. Rosenfeld PJ, Brown DM, Heier JS, Boyer DS, Kaiser PK, Chung CY, Kim RY; MARINA Study Group: Ranibizumab for neovascular age-related macular degeneration. N Engl J Med 2006, 355:1419-1431

3. Ferrara N, Gerber HP, LeCouter J: The biology of VEGF and its receptors. Nat Med 2003, 9:669-676

4. Ohno-Matsui K, Hirose A, Yamamoto S, Saikia J, Okamoto N, Gehlbach P, Duh EJ, Hackett S, Chang M, Bok D, Zack DJ, Campochiaro PA: Inducible expression of vascular endothelial growth factor in adult mice causes severe proliferative retinopathy and retinal detachment. Am J Pathol 2002, 160:711-719

5. Okamoto N, Tobe T, Hackett SF, Ozaki H, Vinores MA, LaRochelle W, Zack DJ, Campochiaro PA: Transgenic mice with increased expression of vascular endothelial growth factor in the retina: a new model of intraretinal and subretinal neovascularization. Am J Pathol 1997, 151:281-291

6. Oshima Y, Oshima S, Nambu H, Kachi S, Hackett SF, Melia M, Kaleko M, Connelly S, Esumi N, Zack DJ, Campochiaro PA: Increased expression of VEGF in retinal pigmented epithelial cells is not sufficient to cause choroidal neovascularization. J Cell Physiol 2004, 201:393-400

7. Schwesinger C, Yee C, Rohan RM, Joussen AM, Fernandez A, Meyer TN, Poulaki V, Ma JJ, Redmond TM, Liu S, Adamis AP, D'Amato RJ: Intrachoroidal neovascularization in transgenic mice overexpressing vascular endothelial growth factor in the retinal pigment epithelium. Am J Pathol 2001, 158:1161-1172

8. Comparison of Age-related Macular Degeneration Treatments Trials (CATT) Research Group, Maguire MG, Martin DF, Ying GS, Jaffe GJ, Daniel E, Grunwald JE, Toth CA, Ferris FL III, Fine SL: Five-year outcomes with anti-vascular endothelial growth factor treatment of neovascular age-related macular degeneration: the Comparison of Age-Related Macular Degeneration Treatments Trials. Ophthalmology 2016, 123:1751-1761

9. Kovach JL, Schwartz SG, Flynn HW Jr, Scott IU: Anti-VEGF treatment strategies for wet AMD. J Ophthalmol 2012, 2012:786870

10. Rofagha S, Bhisitkul RB, Boyer DS, Sadda SR, Zhang K; SEVENUP Study Group: Seven-year outcomes in ranibizumab-treated patients in ANCHOR, MARINA, and HORIZON: a multicenter cohort study (SEVEN-UP). Ophthalmology 2013, 120:2292-2299

11. Scott AW, Bressler SB: Long-term follow-up of vascular endothelial growth factor inhibitor therapy for neovascular age-related macular degeneration. Curr Opin Ophthalmol 2013, 24:190-196 
12. Takeda AL, Colquitt J, Clegg AJ, Jones J: Pegaptanib and ranibizumab for neovascular age-related macular degeneration: a systematic review. Br J Ophthalmol 2007, 91:1177-1182

13. Foxton RH, Finkelstein A, Vijay S, Dahlmann-Noor A, Khaw PT, Morgan JE, Shima DT, Ng YS: VEGF-A is necessary and sufficient for retinal neuroprotection in models of experimental glaucoma. Am J Pathol 2013, 182:1379-1390

14. Nishijima K, Ng YS, Zhong L, Bradley J, Schubert W, Jo N, Akita J, Samuelsson SJ, Robinson GS, Adamis AP, Shima DT: Vascular endothelial growth factor-A is a survival factor for retinal neurons and a critical neuroprotectant during the adaptive response to ischemic injury. Am J Pathol 2007, 171:53-67

15. Saint-Geniez M, Maharaj AS, Walshe TE, Tucker BA, Sekiyama E, Kurihara T, Darland DC, Young MJ, D'Amore PA: Endogenous VEGF is required for visual function: evidence for a survival role on muller cells and photoreceptors. PLoS One 2008, 3:e3554

16. Wang Y, Wang VM, Chan CC: The role of anti-inflammatory agents in age-related macular degeneration (AMD) treatment. Eye (Lond) 2011, 25:127-139

17. Morohoshi K, Goodwin AM, Ohbayashi M, Ono SJ: Autoimmunity in retinal degeneration: autoimmune retinopathy and age-related macular degeneration. J Autoimmun 2009, 33:247-254

18. Edwards AO, Ritter R III, Abel KJ, Manning A, Panhuysen C, Farrer LA: Complement factor $\mathrm{H}$ polymorphism and age-related macular degeneration. Science 2005, 308:421-424

19. Hageman GS, Anderson DH, Johnson LV, Hancox LS, Taiber AJ, Hardisty LI, Hageman JL, Stockman HA, Borchardt JD, Gehrs KM, Smith RJ, Silvestri G, Russell SR, Klaver CC, Barbazetto I, Chang S, Yannuzzi LA, Barile GR, Merriam JC, Smith RT, Olsh AK, Bergeron J, Zernant J, Merriam JE, Gold B, Dean M, Allikmets R: A common haplotype in the complement regulatory gene factor $\mathrm{H}$ $(\mathrm{HF} 1 / \mathrm{CFH})$ predisposes individuals to age-related macular degeneration. Proc Natl Acad Sci U S A 2005, 102:7227-7232

20. Haines JL, Hauser MA, Schmidt S, Scott WK, Olson LM, Gallins P, Spencer KL, Kwan SY, Noureddine M, Gilbert JR, SchnetzBoutaud N, Agarwal A, Postel EA, Pericak-Vance MA: Complement factor $\mathrm{H}$ variant increases the risk of age-related macular degeneration. Science 2005, 308:419-421

21. Klein RJ, Zeiss C, Chew EY, Tsai JY, Sackler RS, Haynes C, Henning AK, SanGiovanni JP, Mane SM, Mayne ST, Bracken MB, Ferris FL, Ott J, Barnstable C, Hoh J: Complement factor H polymorphism in age-related macular degeneration. Science 2005, 308: 385-389

22. Espinosa-Heidmann DG, Suner IJ, Hernandez EP, Monroy D, Csaky KG, Cousins SW: Macrophage depletion diminishes lesion size and severity in experimental choroidal neovascularization. Invest Ophthalmol Vis Sci 2003, 44:3586-3592

23. Lopez PF, Grossniklaus HE, Lambert HM, Aaberg TM, Capone A Jr, Sternberg P Jr, L'Hernault N: Pathologic features of surgically excised subretinal neovascular membranes in age-related macular degeneration. Am J Ophthalmol 1991, 112:647-656

24. Oh H, Takagi H, Takagi C, Suzuma K, Otani A, Ishida K, Matsumura M, Ogura Y, Honda Y: The potential angiogenic role of macrophages in the formation of choroidal neovascular membranes. Invest Ophthalmol Vis Sci 1999, 40:1891-1898

25. Sakurai E, Anand A, Ambati BK, van Rooijen N, Ambati J: Macrophage depletion inhibits experimental choroidal neovascularization. Invest Ophthalmol Vis Sci 2003, 44:3578-3585

26. Kaarniranta K, Salminen A: Age-related macular degeneration: activation of innate immunity system via pattern recognition receptors. J Mol Med (Berl) 2009, 87:117-123

27. Kumar MV, Nagineni CN, Chin MS, Hooks JJ, Detrick B: Innate immunity in the retina: Toll-like receptor (TLR) signaling in human retinal pigment epithelial cells. J Neuroimmunol 2004, 153:7-15

28. Ambati J, Atkinson JP, Gelfand BD: Immunology of age-related macular degeneration. Nat Rev Immunol 2013, 13:438-451
29. Gay NJ, Gangloff M: Structure and function of Toll receptors and their ligands. Annu Rev Biochem 2007, 76:141-165

30. Oliveira-Nascimento L, Massari P, Wetzler LM: The role of TLR2 in infection and immunity. Front Immunol 2012, 3:79

31. West XZ, Malinin NL, Merkulova AA, Tischenko M, Kerr BA, Borden EC, Podrez EA, Salomon RG, Byzova TV: Oxidative stress induces angiogenesis by activating TLR2 with novel endogenous ligands. Nature 2010, 467:972-976

32. Grote K, Schutt H, Schieffer B: Toll-like receptors in angiogenesis. ScientificWorldJournal 2011, 11:981-991

33. Beatty S, Koh H, Phil M, Henson D, Boulton M: The role of oxidative stress in the pathogenesis of age-related macular degeneration. Surv Ophthalmol 2000, 45:115-134

34. Erridge C: Endogenous ligands of TLR2 and TLR4: agonists or assistants? J Leukoc Biol 2010, 87:989-999

35. Saeed AM, Duffort S, Ivanov D, Wang H, Laird JM, Salomon RG, Cruz-Guilloty F, Perez VL: The oxidative stress product carboxyethylpyrrole potentiates TLR2/TLR1 inflammatory signaling in macrophages. PLoS One 2014, 9:e106421

36. Fujimoto T, Sonoda KH, Hijioka K, Sato K, Takeda A, Hasegawa E, Oshima Y, Ishibashi T: Choroidal neovascularization enhanced by Chlamydia pneumoniae via Toll-like receptor 2 in the retinal pigment epithelium. Invest Ophthalmol Vis Sci 2010, 51: 4694-4702

37. Zhu Y, Liang L, Qian D, Yu H, Yang P, Lei B, Peng H: Increase in peripheral blood mononuclear cell Toll-like receptor 2/3 expression and reactivity to their ligands in a cohort of patients with wet agerelated macular degeneration. Mol Vis 2013, 19:1826-1833

38. Kalayoglu MV, Bula D, Arroyo J, Gragoudas ES, D’Amico D, Miller JW: Identification of Chlamydia pneumoniae within human choroidal neovascular membranes secondary to age-related macular degeneration. Graefes Arch Clin Exp Ophthalmol 2005, 243:1080-1090

39. Nagai N, Ju M, Izumi-Nagai K, Robbie SJ, Bainbridge JW, Gale DC, Pierre E, Krauss AH, Adamson P, Shima DT, Ng YS: Novel CCR3 antagonists are effective mono- and combination inhibitors of choroidal neovascular growth and vascular permeability. Am J Pathol 2015, 185:2534-2549

40. Nagai N, Lundh von Leithner P, Izumi-Nagai K, Hosking B, Chang B, Hurd R, Adamson P, Adamis AP, Foxton RH, Ng YS, Shima DT: Spontaneous CNV in a novel mutant mouse is associated with early VEGF-A-driven angiogenesis and late-stage focal edema, neural cell loss, and dysfunction. Invest Ophthalmol Vis Sci 2014, 55: 3709-3719

41. Doyle SL, Lopez FJ, Celkova L, Brennan K, Mulfaul K, Ozaki E, Kenna PF, Kurali E, Hudson N, Doggett T, Ferguson TA, Humphries P, Adamson P, Campbell M: IL-18 immunotherapy for neovascular AMD: tolerability and efficacy in nonhuman primates. Invest Ophthalmol Vis Sci 2015, 56:5424-5430

42. Maminishkis A, Miller SS: Experimental models for study of retinal pigment epithelial physiology and pathophysiology. J Vis Exp 2010, 45:2032

43. Iacovelli J, Rowe GC, Khadka A, Diaz-Aguilar D, Spencer C, Arany Z, Saint-Geniez M: PGC-1alpha induces human RPE oxidative metabolism and antioxidant capacity. Invest Ophthalmol Vis Sci 2016, 57:1038-1051

44. Zarember KA, Godowski PJ: Tissue expression of human Toll-like receptors and differential regulation of Toll-like receptor mRNAs in leukocytes in response to microbes, their products, and cytokines. J Immunol 2002, 168:554-561

45. Buwitt-Beckmann U, Heine $\mathrm{H}$, Wiesmuller KH, Jung $\mathrm{G}$, Brock R, Akira S, Ulmer AJ: Toll-like receptor 6-independent signaling by diacylated lipopeptides. Eur J Immunol 2005, 35: 282-289

46. Detrick B, Hooks JJ: Immune regulation in the retina. Immunol Res 2010, 47:153-161

47. Crabb JW, Miyagi M, Gu X, Shadrach K, West KA, Sakaguchi H, Kamei M, Hasan A, Yan L, Rayborn ME, Salomon RG, 
Hollyfield JG: Drusen proteome analysis: an approach to the etiology of age-related macular degeneration. Proc Natl Acad Sci U S A 2002, 99:14682-14687

48. Gu X, Meer SG, Miyagi M, Rayborn ME, Hollyfield JG, Crabb JW, Salomon RG: Carboxyethylpyrrole protein adducts and autoantibodies, biomarkers for age-related macular degeneration. J Biol Chem 2003, 278:42027-42035

49. Tseng WA, Thein T, Kinnunen K, Lashkari K, Gregory MS, D'Amore PA, Ksander BR: NLRP3 inflammasome activation in retinal pigment epithelial cells by lysosomal destabilization: implications for age-related macular degeneration. Invest Ophthalmol Vis Sci 2013, 54:110-120
50. Cousins SW, Espinosa-Heidmann DG, Miller DM, Pereira-Simon S, Hernandez EP, Chien H, Meier-Jewett C, Dix RD: Macrophage activation associated with chronic murine cytomegalovirus infection results in more severe experimental choroidal neovascularization. PLoS Pathog 2012, 8:e1002671

51. Miller DM, Espinosa-Heidmann DG, Legra J, Dubovy SR, Suner IJ, Sedmak DD, Dix RD, Cousins SW: The association of prior cytomegalovirus infection with neovascular age-related macular degeneration. Am J Ophthalmol 2004, 138:323-328

52. Wooten RM, Ma Y, Yoder RA, Brown JP, Weis JH, Zachary JF, Kirschning CJ, Weis JJ: Toll-like receptor 2 is required for innate, but not acquired, host defense to Borrelia burgdorferi. J Immunol 2002, 168:348-355 